\title{
Front Matter: Volume 11456
}

, "Front Matter: Volume 11456," Proc. SPIE 11456, Optical Fibers and Their Applications 2020, 1145601 (12 June 2020); doi: 10.1117/12.2574574

SPIE. Event: Optical Fibers and Their Applications 2020, 2020, Bialowieza, Poland 


\title{
PROCEEDINGS OF SPIE
}

\section{Optical Fibers and Their Applications 2020}

\author{
Ryszard S. Romaniuk \\ Jan Dorosz \\ Editors
}

\section{7-31 January 2020 \\ Białowieża, Poland}

Organized by

Faculty of Electrical Engineering, Białystok University of Technology (Poland)

Polish Association of Theoretic al and Applied Electric al Eng ineering (Poland)

\section{Patronage}

Committee of Electronics and Telecommunic ations, Polish Academy of Sciences

Photonics Soc iety of Poland

Polish Optoelec tronic sC ommittee, Assoc iation of Polish Electric al Engineers

Published by

SPIE

Volume 11456 
The papers in this volume were part of the technical conference cited on the cover and title page. Papers were selected and subject to review by the editors and conference program committee. Some conference presentations may not be available for publication. Additional papers and presentation recordings may be availa ble online in the SPIE Digital Libra ry at SPIEDigita lLibra ry.org.

The papers reflect the work and thoughts of the authors and a re published herein as submitted. The publisher is not responsible for the validity of the infomation or for any outcomes resulting from reliance thereon.

Please use the following format to cite material from these proceedings:

Author(s), "Title of Paper," in Optical Fibers and Their Applic ations 2020, edited by

Ryszard S. Romaniuk, Jan Dorosz, Proceedings of SPIE Vol. 11456 (SPIE, Bellingham, WA, 2020) Sevendigit Article CID Number.

ISSN: 0277-786X

ISSN: 1996-756X (electronic)

ISBN: 9781510637153

ISBN: 9781510637160 (electronic)

Published by

SPIE

P.O. Box 10, Belling ham, Washington 98227-0010 USA

Telephone +1 3606763290 (Pacific Time)· Fax +1 3606471445

SPIE.org

Copyright @ 2020, Society of Photo-Optic al Instrumentation Engineers.

Copying of material in this book for intemal or personal use, or for the intemal or personal use of specific clients, beyond the fair use provisions granted by the U.S. Copyright Law is authorized by SPIE subject to payment of copying fees. The Transactional Reporting Service base fee for this volume is $\$ 21.00$ per article (or portion thereof), which should be paid directly to the Copyright Clearance Center (CCC), 222 Rosewood Drive, Danvers, MA 01923. Payment may also be made electronically through CCC Online at copyright.com. Other copying for republication, resale, advertising or promotion, or any form of systematic or multiple reproduction of any material in this book is prohibited except with permission in writing from the publisher. The CCC fee code is 0277$786 \times / 20 / \$ 21.00$.

Printed in the United States of Americ a by Curran Associates, Inc., under license from SPIE.

Public ation of record for individual papers is online in the SPIE Digital Libra ry.

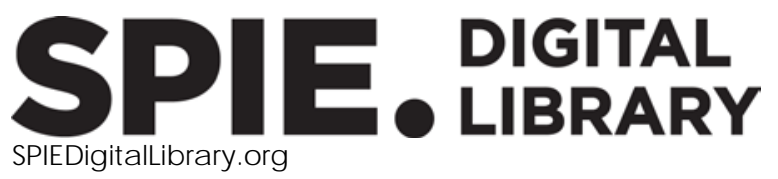

Paper Numbering: Proceedings of SPIE follow an e-First publication model. A unique citation identifier (CID) number is assigned to each article at the time of publication. Utilization of CIDs allows articles to be fully citable as soon as they are published online, and connects the same identifier to all online and print versions of the publication. SPIE uses a seven-digit CID article numbering system struc tured as follows:

- The first five digits correspond to the SPIE volume number.

- The last two digits indicate publication order within the volume using a Base 36 numbering system employing both numerals and letters. These two-number sets start with $00,01,02,03,04$, 05, 06, 07, 08, 09, OA, OB ... 0Z, followed by 10-1Z, 20-2Z, etc. The CID Number appears on each page of the manuscript. 


\section{Contents}

v Introduction

CONHRENCE OVERIEW

1145602 Development of optical fibertechnology in Poland 2020 (Invited Paper) [11456-1]

OPTICALMATIRIALS, GLASSES, UQUID CRYSTALS, OPIICALFBRESAND COMPONENTS

$1145603 \quad$ New multic omponent titanate-gemanate glasses and their luminescence properties [11456-7]

1145604 Biological properties of rare-earth doped bioactive glass [11456-10]

1145605 Optical parameters of (Gao.4Ino.6)2Se3 thin film [11456-22]

1145606 J ones-matrix mapping of polycrysta lline networks of layers of main types of amino acids [11456-23]

1145607 Femtosecond pulse delivery around $1560 \mathbf{~ m m}$ in large-core ant-resonant fibers [11456-4]

1145608 Design of multi-order diffractive intraocular lenses [11456-24]

1145609 Technology of infrared radiation polarizer [11456-25]

11456 OA Relationship between the technique of integral equation and Kirchhoff approximation in scalar diffraction theory [11456-26]

PHOTONIC SENSORS, IMAGE PROC ESSING, MEDICALAPPUCATIONS

11456 OC Lightning impulse withstand tests for optical fiber current sensor with extemal conversion [11456-8]

11456 OD Analysis of atherosclerotic lesions in the human body [11456-11]

$11456 \mathrm{OE} \quad$ Modification of existing methods of visualization of offset face skin structure [11456-13]

11456 OF Optical-frequency gas flow meter on the basis of transistor structures with negative differential resistance [11456-14] 
11456 OG Possibilities of automated image processing at optical capilla roscopy [11456-15]

$11456 \mathrm{OH} \quad$ Features of image analysis under UV-video demoscopy [11456-16]

11456 ol ROC analysis of informativeness of mapping of the elliptic ity distributions of blood plasma films laser images polanization in the evaluation of pathological changes in the breast [11456-17]

11456 0] Method of using laser doppler flowmetry in assessment of the state of blood mic rocirculation system [11456-18]

11456 OK Laser doppler for diagnosis of changes of microcirc ulation in the perioperal period in patients with ac ute adhesive obstruction of small gut [11456-19]

$11456 \mathrm{OL}$ Automated features analysis of patients with spinal diseases using medical themal images [11456-20]

11456 OM Research of the ellipsoid area geometry illuminated by a point laser source [11456-21]

OPICALFBRE COMMUNICATIONS

11456 ON Transport of Rel-15/ 16 waveform radio signa ls over optical 5G fronthaul path [11456-5]

1145600 Potential use of fiber-optic and L-F systems in private 5G/6G networks dedicated to the industrial loT (Invited Paper) [11456-6]

11456 OP Operators' view of the FTH/ mobile fiber network convergence (Invited Paper) [11456-9] 


\section{Introduction}

Symposium on "Optic al Fibers and Their Application" OFTA is a forum of national science in this branch of Photonics. The Symposium also hosts numerable guests from this geographical region, and especially from neighboring countries and Europe. It is orga nized every yearand a ha If by two major optic al fibertechnology and application development centers located in Białystok at Białystok University of Technology, and in Lublin at Maria Curie-Skłodowska University UMCS and the Technic al University of Lublin. The conference belongsto a biggercircle of national meetings on optoelectronics, optics, photonics, sensors and laser technology which are under a general patronage of professoressional community organizations like the Polish Physic al Society - Section of Optics, the Polish Cera mic Society, the Photonic s Soc iety of Poland, Polish Optoelectronics Committee of the Association of Polish Electrical Engineers, Section of Photonics in the Committee of Electronics and Telecommunications, Polish Academy of Sciences, and Polish Association of Theoretical and Applied Electrical Engineering.

Forty-five yearsago, duning the year of 1975, there was bom fibre optic technology in the countryof Poland. The Department of Physical Chemistry cha ired by Professor Andrzej Waksmund zki at the Department of Chemistry in University of Maria CurieSkłodowska in Lublin started working on a modification of the glass capillary for optical signal transmission purposes and implemented successfully there a few years later the MCVD technology of high quality silic a optical fibres. The works on fibre-optic technology with soft glasses a lso begun in other scientific institutions like ITME in Warsaw and technological tests began soon afterwards in Glassworks Bia lystok and Bialystok Technical University. Simulta neously the country worked on the active elements for fibre optics, including photodiodes and light-emitting diodes and semic onductorlasers which were actively conducted in ITE in Warsaw. Several persons, including the late university professors were involved in initiating and supporting the OFTA conferences at their early stage: J.Groszkowski, A.Smoliński, A.Waksmundzki, M.Pluta, B.Pa szkowski, ZSzpigler, J.Wójcik, K.Holejko, J.Rayss, S.Sońta. The relatively easy availability in the country of numerous samples of various kind sof optical fibres, ma nufactured by MCVD and other modified and hybrid multi-staged methods, as well as DC, MC and RIT methods with different silic a and multicomponent glasses, practic ally since the mid and late seventies has played a fundamental role in the development of the fibre optics and photonics, research and technical community in Poland. One can say, without any exaggeration, that in the absence in the country of such cheap samples, available virtually for free and on-demand for all other laboratories, today the fields of photonics and fibre optics, but also lasertechnologies would be different, much more modest. Did the created community manage in some way to repay the developers of technology for such a unique opportunity to develop their own and rich photonicsapplic ation? In general, yes, because the gifted technolog ists often helped out in the pioneering application work. In addition, the application works 
used to give a strong impetus to the development of new optic al fibre structures, and stimulated search for technology developments. The country has created a positive feedback mechanism between technology, metrology, fibre optic photonics theory and research applications, and even some pioneering industries. The three mentioned and described fibre optic technology centres, significantly different from each other by research professoriles and interest and involved in quite different types of fib re were then a mplified by the work on high quality gla sses and optical and photonics materials camied out at the Institute of Glass and Ceramics, AGH and Silesian University of Technology, as well as other centres.

The First National Symposium on "Optical Fibres a nd Their Applic ations", orga nized in the Polish Academy of Sciences Palace in Jabłonna in February 1976, was sa real breakthrough event for the local research communities in optoelectronic $s$, as could be seen today from the perspective of several decades after that meeting. The initiator of the first and several subsequent meetings was professor Adam Smoliński from Warsaw University of Technology. Since then, Optical Fibre Symposia are accompanying the development of photonics in the country and create their unique scientific documentation. The Symposia have always gathered and are gathering still today a large group of young people. The first fibre optic meeting was attended by 100 people. The Symposium in Jabłonna turned into a constant cycle of scientific meetings which lasts until today. During the First Symposium there were delivered two technologic al works on attemptsto ma nufacture optical fibers in the centers of Lublin and Warsaw and a review by professor Bohdan Paszkowski of the manufacturing methods of optical fibers in the leading centers in the world. Other works presented at the First National Symposium concemed several topics like: the outlook of the birth of fiber optic telecommunic ations by professor Zenon Szpigler, review of the progress of integrated optics using planar optical waveguides and components, first tests of fiber optic transmission in the country, medical and instrumental a pplic ations using fiber optics developed in the country, optoelectronic components for fiber optics - sources and detectors and measurements of optoelectronic components. Part of plenary lectures at the symposium was delivered by foreign experts, representa tives of lea ding European optical fiber laboratories like CNET Lannion, ISPT Rome, TU Braunschweig, Univ. Southampton. A large part of the national work, especially those given by a cademics, had survey and prognostic character, but several works, given by then young researchers concemed their own technological, instrumentation and transmission experiments. A full book of the Symposium Proc eed ingswa spublished.

The second general summary meeting for technological, theoretical and application works of the national research fibre optics community took place during the Second National Symposium on "Optic al Fibres and Their Applic ations", which washeld on 13-15 February 1979, a lso in the Pa lace of Sciences in Jabłonna. The meeting was attended by approximately 150 people. During the symposium there were published several key works from the optical fibre technology centres in Lublin, Warsaw and Bialystok. There were presented several tec hnological works on the production of optical fibers by double-crucible method, MCVD and PCVD 
methodsas well astechnological works on optoelectronic components and works of fibre metrology. Topical sessions during the symposium were: optical fibre technology and theory, optical radiation sources and detectors, surveying of optoelectronic devices and systems for telecommunications, non-telecom application usage of fibre optics, sensors and integrated optics components. Symposium works were issued in two volumes in Polish and an English volume of extended abstracts.

The Third OFTA Symposium was preceded by two side meetings: Optical Fibre Measurement Techniques, Lublin 1981, and Non-telecommunications Optical Fibres in Białowieża 1982. These high technology topical conferences gathered 100 participants each. The Third Symposium on Optical Fibers and Their Applications was expected to be held in 1982 (16-18 February), but due to some well-known system and organization issues in Poland was postponed to 1983 and was held on 15-1 7 February 1983 in Jabłonna. The symposium gathered much more participants than the previous ones because there partic ipated more than 250 people and 20 foreign guests, whic h numberfarexceeded the capacity of the small but bea utiful palace in Jabłonna. In total, there were delivered approximately 30 plenary papers and presented more than 150 contributed papers including many directly related to optical fibre manufacturing technology. Again, there were represented all three technology centres from Lublin, Warsaw and Białystok. The organization rule of the IIIrd Symposium in Jabłonna was like the previous ones. Plenary papers, in the form of invited lectures - tutorials were delivered by the world's leading representatives of this tec hnique. National presentations were displayed in a few thematic poster sessions, which were preceded by wider introductory presentations in digest style. The topical sessions of the national work were as follows: optical fibre communications; optical fibre - technology, theory, measurements; sources and detectors for optical fibres; optical fibre passive components - couplers, connectors, switches and sensors; integrated optoelec tronics - theory, technology, la boratory experiments; a pplic ations of fiber optics - scientific, industrial, biomedical. Five volumes of proceedings were published, four in Polish and one in English.

The series of conferences on "Optical Fibers and Their Applications" OFTA were suc cessfully continued. Subsequent conferences, the IVth and the Vth, due to the much larger number of participants, took place in the Palace of Culture and Science in Warsaw, still every three years, in 1986 and 1989. After that there was a change in the rule and the next OFTA conferences were continued with considerable organizational succ ess by technologic al research centres in Bia lystok and Lublin. Initially, however, they were numbered separately and then again together. The conferences started to be organized every year and a half. The dominant theme of the meetings done by Bialystok were, in the initial period, the applications of fibre optics and technology of non-telecom optical fibres. The Lublin meetings were concentrated on optical fibre transmission technology. Currently, these two series of meetings a re still orga nized every year and a half in September by Lublin and in January by Białystok, and they are the most important 
events summarizing periodic ally the achievements of the national scientific and technical OFT community. Below there is a list of conferences continued within the cycle on Optical Fibers and Their Applications. The cycle is supplemented with additional important events, which were also dedic ated to fiberoptic technology, as a Congress on Optic sand Optoelectronic s by SPIE, organized in 2005 in Warsa w and the European Conference-Workshop of Optical Fibre Sensors EWOFS, 2013 Krakow, WILGA a nnual meetings on Photonic sApplic ations, and Laser Technology Symposium.

1976 - I-OFTA (Optical Fibres and Their Applications) Jabłonna 16-18.02.1976; 1979 - II-OFTA Jabłonna, 13-15.02.1979;

1981 - Optical Fibre Measurement Technology, Nat. Symp., Lublin VI 1981;

1982 - Non-Telecommunications Optical Fibres, Nat. Symp., Białystok-Białowieża 1982;

1983 - III-OFTA, Jabłonna (1982) 15-17.02.1983;

1986 - IV-OFTA - Warszawa, PKiN, 11-13.02.1986, Proc. SPIE 0670; doi:10.1117/12.938955.

1989 - V-OFTA - Warszawa, PKiN, 21-23.02.1989, Proc. SPIE 1085; doi: $10.1117 / 12.952946$

1996 - Technology and Applications of Lightguides, TAL, Kra snobród 17-19.10.1996, Proc. SPIE 3189, 1998 - VI-OFTA - Białystok-Białowieża 22-24.01.1998, Proc. SPIE 3731;

1999 - Lightguides and their Applic ations, Krasnobród, 14-16.10.1999, Proc. SPIE 4239;

2002 - VIII-OFTA, Białystok - Białowieża, 23-25.01.2002, Proc. SPIE 5028;

2002 - Photonics Ap plic ations, Wilga Symposium, 23-26.05.2002, Proc. SPIE 5125;

2003 - Lightguides and their Applic ations II, Krasnobród, 9-11.10.2003, Proc. SPIE 5576 ;

2005 - SPIE Congress on Optics and Optoelectronics (COO) in Warszawa, 28.0802.09.2005, Proc. SPIE 5948, 5950, 5951;

2006 - (X-OFTA) Lightguides and Their A pplic ations III, Krasnobród , 4-7.10.2006, Proc. SPIE 6608;

2008 - XI-OFTA - Białystok and Białowieża, 30.01-02.02.2008, Proc. SPIE 7120;

2009 - XII-OFTA - Lublin and Krasnobród, 14-17.10.2009;

2011 - XIII-OFTA - Białystok and Białowieża, 26-29.01.2011; Proc. SPIE 8010;

2012 - XIV-OFTA - Lublin and Nałęczów, 10-13.10.2012; Proc . SPIE 8698;

2013 - EWOFS Kraków 05.2013, Proc. SPIE 8794;

2014 - XV-OFTA - Białystok and Lipowy Most, 29.01-01.02.2014; Proc. SPIE 9228;

2015 - XVI-OFTA - Lublin and Nałęczów, 22-25.09.2015; Proc. SPIE 9816;

2017 - XVII-OFTA - Białystok and Supraśl; 23-27.01.2017; Proc. SPIE 10325, doi:10.1117/12.2275494;

2018 - XVIII-OFTA - Lublin and Nałęczów, 19-23.11.2018; Proc. SPIE 11045, doi:10.1117/12.2530349;

2020 - XIX-OFTA - Białowieża, 27-31.01.2020, Proc. SPIE

2020 - XLVI-WILGA Photonic sApplications, 25-31.05.2020, Proc . SPIE in edition; 
2020 - Symposium on Laser Technology, Karpacz near Wrocław, 21-25.09.2020;

2021 - XX-OFTA - Lublin and Nałęczów, planned in September 2021;

Nałęczów was hosting the Sixteenth Conference and School on "Optical Fibres and Their Applications" on 22-25 September 2015. The conference was included in the worldwide series of events to celebrate the Intemational Year of Light YL2015 [www.light2015.org]. The orga nizers of OFTA 2015 meeting were the Department of Tec hnology of Fiber Optic s in the Faculty of Chemistry of Maria C unie-Skłodowska University in Lublin, and the Faculty of Electrical Engineening and Computer Sc ience, Technical University of Lublin. The a im of the conference was traditionally to enable the direct discussion of relevant research and technical groups, which are actively involved in the main areas of optical fibre photonics. An additional element of the Conference was the organization of the fourth workshop on fibre optic technology for students and doctoral students in technologic al laboratories of Optical Fibre Technology Department of the UMCS in Lublin. This action allows young scientists to better understand what opportunities and limitations of practical laboratory and application work with optic al fibre devic es and photonic components are. The XVIth OFTA2015 Conference was held 40 years after the start of the country's work on fibre optic technology. There was an opportunity to organize the J ubilee Session and remind of some facts, institutions, and above all those people who were associated with the origins of this field of photonics in Poland. The 2015 Nałęczów Conference gathered around 120 participants. There were presented over 80 papers in oral nd poster sessions. The biggest groups of papers orig inated from such university centers a ctive in optoelectronic s as: Silesian Uni. of Technology in Gliwice, Białystok, Warsaw and Lublin as well as UMCS in Lublin. The topical coverage of the Symposium was: materials for optoelectronics - materials for optic al fiber technology, fabrication of optical fibers, components and sub-assemblies for optoelectronics, metrology of optical fibers, metrology of optoelec tronic components and devices, a pplic ations of optic al fibers, education in optoelectronics and photonics. There were presented a few plenary papers touching very current and hot problems in optoelectronics.

The Seventeenth Conference on "Optic al Fibres and Their Applic ations 2017" was organized' in Supraśl on 23-27 J a nua ry 2017, by the Fa culty of Elec trical Engineening of Białystok University of Technology in co-operation with the Polish Society of Theoretical and Applied Electric al Engineening. Traditionally the patrons of these serial meeting sa re the Committee of Electronic sand Telec ommunic a tions of Polish Academy of Sciences, Polish Optoelectronics Committee of the Association of Polish Electrical Engineers, Photonics Society of Poland, and Polish Ceramics Society. The conference has gathered over 120 participants from leading photonics technology centers in Poland. Approximately 60 plenary papers and 40 posters were presented. The conference's topical sessions were concentrated around: hot topics of optical fibre photonics, materials for optical fibres and photonics including new glass synthesis for IR fibres, nonlinear and active glasses for optical fibres, polymer optical fibres, special optical fibres for functional components and sensors, optical fibre sensors solutions, optical fibre 
communications and networks including PON-WDM, and photonic integrated circuits. The detailed conference subjects embraced:

- technology development and manufacturing of optical fibres: classical, telecom, sensory and microstructural; optical fibre cables; planar optical waveguides and components; integrated optics and micro-optics; optical, optoelectronic, photonic and optic al fibre sensors.

- fibre optics components, passive and active, such as couplers, power dividers, connectors, optical insulators, fibre circulators, nonreciprocal devices, optical amplifiers, optical and optoelectronic devices for connecting optic al fibres with light sources and receivers, optical fibre and planar multiplexers and demultiplexers, etc.

- fibre applic a tions especially those that require close cooperation with specialists producing optical fibres, optical cables, transmission channels, and elements of fibre optics, optoelectronics and photonics.

- education in the field of photonics in universities and secondary schools, continued training in professoressional sc hools.

The proceedings of the XVIlth OFTA Conference were tra ditionally published in the world wide book series on optics and photonics, the Proceedings of SPIE. The 2017 OFTA Conference has summarized in a vivid way the current technological achievements of the three major fibre optic technology centres in Lublin, Bialystok and Warsaw; but also other technologic al centres active in research on materials for photonic s and optoelectronic s: glasses, polymers, semic onductors; as well as numerous academic and industrial centres of photonics fibre optic applications. Technology and application centres of photonics and fiber optic s a re numerous today and active across the country. One can mention some of them: AGH, Warsaw University of Technology (IMiO, ISE, ITele, at the Faculties of Electronics, Mechatronics, and Physics), WAT, at the Technic al Universities in Wroclaw, Poznan, Gdansk, Katowice and Gliwice, and other Institutes like ITE, ITR, TMME, a nd a growing number of research companies and high-tech industries, like Vigo, Fibrain, InPhoTech and others.

During the days of 19 to 23 November 2018 there was held the XVIllth Conference on "Optical Fibers and Their Applications". The Conference was opened at the Energetyk Resort in Nałęczów, near Lublin, but the accompanying School/Workshop on Optical Fiber Technology was held in Lublin at UMCS OFT Laboratory on 19 November. The XVIllth Conference was opened by professor WaldemarWójcik at the presence of the Dean of the Faculty of Chemistry of UMCS. The national expertise in optical fibers was gathered during the recent years around several big organizations, some of them with intemational roots: Section of Optoelectronics, Committee of Electronics and Telecommunications, Polish Academy of Sciences; Polish Committee of Optoelectronics, Association of Polish Electrical Engineers; Polish Chapter of SPIE - The Intemational Soc iety for Optic al Engineering. The latter organization registered in this country as a Society and was transformed in 2008 to the Photonics Society of Poland. These organizations cooperate with SPIE - The Intemational Society for Optics and Photonics, IEEE 
Poland Section and Photonic sChapter, Section of Optics by Polish Physic al Soc iety and Polish Ceramic Society.

During the conference opening ceremony professor W.Wójcik reminded everybody of the history of the OFTA Nałęczów Conferences. The national experts of guided wave, laser and semic onductor optoelectronics meeting in Krasnobród, Nałęczów, Białowieża, Lipowy Most, and Świnoujście (Laser Technology Symposium) managed to integrate their activities in the frame of numerous optoelectronics research programs camied out duning these years. These were programs: national, central, departmental, prionity, university and recently also European realized with a number of intemational partners. Realization of these projects lead to numerous scientific and technic al a chievements as well as being the underlying factors for establishing several photonic fims in this country and modemizing the instruction at technical universities. The 2018 Nałęczów Conference gathered around 120 partic ipants. Over 80 papers in oral and poster sessions were presented. The biggest groups of papers originated from such university centers a ctive in optoelec tronics as: Silesian University of Technology in Gliwice, Białystok, Warsaw and Lublin as well as UMCS in Lublin. The topical coverage of the Symposium was: materials for optoelectronics: materials for optical fiber technology, fabrication of optical fibers, components and subassemblies for optoelectronics, metrology of optical fibers, metrology of optoelectronic components and devices, a pplic ations of optic al fibers, education in optoelectronics and photonics. There were presented a few plenary papers touching very current and hot problems in optoelectronics. The technological sessions of the symposium presented the works from three main national centers where optical fibers a re pulled. These a re: Fa culty of Chemistry, University of Ma ria Curie Skłodowska in Lublin, Faculty of Electrical Engineering at Białystok University of Technology and Institute of Electronic Materials Technology in Warsaw. Numerable papers were presented from the research firms and the industry, including InPhoTech, Fibra in and Polish Centre for Photonics and Optical Fibres. A number of research centers in this country and intemationally use these optical fibers foroptical fiber sensors and photonic instrumentation devices. A large group of applications concemed microstructural photonic optical fibers filled or impregnated with liquid crystals, which are highly nonlinear optical substances, much more nonlinear than glass. This group of papers originated from the laboratories at Warsaw and Wrocław Universities of Technology. But the fibers were manufactured at UMCS in Lublin and at TME in Warsaw. There were also numerous application-oriented contributions from photonic sinnovative fims.

The nineteenth OFTA conference was organized on 27-31 Jaunary 2020 in Białowieża by the optical fibre technology research team from Białystok University of Technology, Faculty of Electrical Engineering under the chaimanship of professor Jan Dorosz. The conference gathered nearly 100 participants from all academic and industrial centers active in optical fibre photonics. Ten topical sessions were organized with over 30 plenary speeches. The conference was opened by professorR. Romaniuk and professorW. Woliński from Warsaw University 
of Technology. The Conference organizers have provided very favorable participation conditions for Ph.D. and M.Sc. students, which participated in the meetings and sessions in large numbers. Most of the papers were presented by young researchers, which supports the belief that this branch of technology is vivid and holds promise for future development. Optical and photonics sciences and technologies are developing very intensely both globally and locally. The local developments add very effectively to the global ones. The XIXth Symposium on Optical Fibers and Their Applications was again a great success for the local research and technical communities. The conference gathered a lot of OFT leaders from the country and geographical region as well as young researchers, which shows how this vivid research area attracts young, gifted minds. The conference, combined with celebrations of forty-five years of OFT development by the local technical community, has shown that the fields of optics and photonics, and specific ally Optical Fibre Technology is in excellent shape in Poland and this region of Europe. The authors thank all older participants of the OFTA Series of National Symposia, and especially those who participated in the first editions of these meetings, for their remarks, reminding us of old facts, etc. The Editors would like to thank all authors from domestic and intemational photonic slaboratories for making this volume of proceedings possible by contributing their research results. 